Man and Nature

L'homme et la nature

\title{
Sancte Socrates: Scottish Reflections on Obedience and Resistance
}

\section{J. C. Stewart-Robertson}

Volume 1, 1982

URI : https://id.erudit.org/iderudit/1011792ar

DOI : https://doi.org/10.7202/1011792ar

Aller au sommaire du numéro

Éditeur(s)

Canadian Society for Eighteenth-Century Studies / Société canadienne d'étude du dix-huitième siècle

ISSN

0824-3298 (imprimé)

1927-8810 (numérique)

Découvrir la revue

Citer cet article

Stewart-Robertson, J. C. (1982). Sancte Socrates: Scottish Reflections on Obedience and Resistance. Man and Nature / L'homme et la nature, 1, 65-79. https://doi.org/10.7202/1011792ar

Copyright (C Canadian Society for Eighteenth-Century Studies / Sociéte canadienne d'étude du dix-huitième siècle, 1982
Ce document est protégé par la loi sur le droit d'auteur. L'utilisation des services d'Érudit (y compris la reproduction) est assujettie à sa politique d'utilisation que vous pouvez consulter en ligne.

https://apropos.erudit.org/fr/usagers/politique-dutilisation/ 


\section{Sancte Socrates: Scottish Reflections on Obedience and Resistance}

Socrates was a suicide. That at least appears to have been the verdict of Sir John Pringle who, in February, 1741, addressed at length the question, whether "self murder be in any Case lawful." Although the "first Head" of the Ancients, and thereby (in Pringle's words) "a sufficient law to them," Socrates stands accused here on two counts: first, as contradicting in practice his own views against suicide ${ }^{2}$; and secondly, as contravening the widely accepted rule that if one is determined to die by one's own hand one should not, like Socrates, die "from a Vanity to Show [that one] was not afraid to die." ${ }^{3}$ Whether this tarnishing of the Socratic image had any lasting effect on Scottish prelectors in the eighteenth century remains to be seen. What is immediately apparent, however, is that in theory as in practice he represented a "Sufficient law to them" in other domains of human activity.

For was not Socrates also the model agriculturalist of the mind? George Turnbull had thought so, and the image was deeply impressed into the educational outlook of the time. ${ }^{4}$ Not the least of those for whom the analogy held promise was Turnbull's own pupil, Thomas Reid. ${ }^{5}$ But he was not alone, especially in his native Aberdeen. "[Socrates'] method of teaching was remarkable," extolled David Fordyce to his students at Marischal College in 1743, "being admirably adapted to human nature." ${ }^{\circ}$ Moreover, at the meetings of the Aberdeen Philosophical Society, the possibility of that method's superiority to any other (previous) mode of instruction was raised by Dr. Gregorie. ${ }^{7}$ The illustrious place already assigned to Socrates by Alexander Gerard in 1765, beside such modern names as "LORD VERULAM" and "Mr. LOCKE," had virtually assured Dr. Gregorie's "preference." 8 As the muchadmired Fordyce had put it, first in his lectures and later in his Dialogues Concerning Education, "Man [himself] was the subject of [Socrates'] Philosophy." Cultivation could reach no higher ground than this. "Let the Foundation of the Socratic Doctrine be what it will," argued Fordyce,

it is certain the Practice built upon it, is just and unexceptionable. For whether we say that the Seeds of all Knowledge are actually sown in the Mind, or that it has the Power of conceiving them, by its own generative Force; the interrogating Method sets this Faculty working, and supplies it with Materials to fashion, nay, frequently forms and prepares those Materials, so that it has Nothing to do but to put them together. Yet such is the peculiar Excellency of this Method, that the Mind, all the while, 
seems to be the sole or principal Artist. It instructs, convinces or confutes itself. ${ }^{10}$

There was obviously much, then, to honour in this man.

But Socrates was also a "Sacrifice," in the words of Thomas Reid, "to the publick weal." In respect of his "individual" character he may well have been, as Pringle suggested, vain in dying; as a "universal" character, however, he was not. ${ }^{11}$ Indeed, to this Glasgow prelector on 11 April, 1765, Socrates appears rather as a living embodiment of the principle of obedience to civil authority. In spite of "hardships" and "injuries" under even "the best Government," in spite of the "iniquity of witnesses or of Judges" in the administration of law, that law commands respect. "Every man," declares Reid, "ought to pay . . . obedience to the Laws of his Country which is necessary to the good estate of Government. No state can subsist without a veneration for its laws. Also a Respect to those who have the administration of Government." 12 Under such terms, the "Conduct" of Socrates can only be regarded as "Noble and worthy of the Prince of Philosophers." "Sancte Socrates," Erasmus had exclaimed, in a burst of Christianizing fervour. "How fortunate are they who await death in such a spirit!" ${ }^{3}$ It is this last face of Socrates, the face of obedience and veneration rather than of guilt or vanity, with which we shall be concerned here.

1. The setting for our inquiry is really threefold. At one side, we are witness to the initial struggle of Adam Smith's successor in the Chair of Moral Philosophy at Glasgow, to define for himself those spheres and principles of "Jurisprudence" and "Politicks" (or political oeconomy) which would form the basis for the concluding portions of his lectures on Pneumatology, to be delivered each spring until his retirement in $1780 .{ }^{14}$ Narrowing the focus we find, under the title of "the third and last part of Natural Jurisprudence which treats of the Rights and Obligations arising from the Political State," 15 a passing but pregnant allusion to "the Doctrine of Non Resistance." ${ }^{16}$ A year later, in 1766, the discussion acquires still wider dimensions. With expansion, moreover, the argument grows more complex, the issue less amenable to clear resolve.

Coinciding with the American Revolution, the center of our picture furnishes a glimpse of a theory under trial, transmuted as it were into positive concern. Again, it is obedience to lawful authority, more specifically the right to resist the "Imposition of Taxes," which commands the prelector's attention. ${ }^{17}$ As it turned out, there was a final test still to come.

Within a few years of his death, therefore, the subject of revolution is once more on the prelector's mind. The forum for his views is now broader. In November, 1794, Reid addresses himself to the Literary Society of Glasgow. A month later, he publishes those same reflections under the title, "On the Danger of Political Innovation," in the Glasgow Courier for 18 December, 1794.

"No young person," reminisced Lord Cockburn, "who came to think for himself soon enough to keep what he heard in remembrance, can ever forget the painful impression made upon him by the intolerance of those times." ${ }^{18}$ Whether, and to what extent, Reid partook of that spirit of intolerance is a 
question which obviously cannot be ignored, and which we will have to raise again. Cockburn's image of the youthful auditor, however, can perhaps be employed to good advantage at this preliminary stage. For as the manuscript evidence clearly suggests, there were numerous occasions when Reid reflected openly upon this matter of "Innovation," without the immediate pressure of what he himself called, in 1794, "atrocious conduct" or at least in philosophical abstraction from it. Those young ears, for example, attending to his apparently extemporaneous comments on the "present disturbances" in the American colonies were treated rather to a lecture on the "rights" of "property" than to a plea for "candour and indulgence" in times of violent stress. ${ }^{19}$ Hence, the late public stand taken by this elder philosopherstatesman must be examined and evaluated not only on its own terms and against its historical setting of revolution and counter-revolutionary debate, but also in the light of those earlier prelections to which a privileged few were granted audience. It is thus to what some young persons came to hear that we turn initially.

2. As first broached on 11 and 12 April, 1765, the case for obedience to the civil magistrate gives every appearance of a firm assurance of principle. Although hindered somewhat by a rough and, from this vantage-point, often cryptic set of notes, one may readily surmise that the relation between magistrates and subject has been designed to favour the former even at the worst of times and to the detriment, indeed suffering, of the latter. The investigation into the origins, forms, and ends of civil government had already opened with the candid admission (was it perhaps a forewarning?) that there can be "no civil Government whatsoever which does not in some degree abridge the liberty of those who live under it." Consequent upon this first principle, Reid was able to deduce not only that a "government of Laws [is] better than independence," but also that "Every Man ought in his Station to contribute his best endeavours for the preservation and defence of such a Government. And to be ready to sacrifice his Life and all that is dear to him in so important a Cause." The grounds for obedience having been securely laid, in both its "Passive" and its "Active" forms, Reid might then feel prepared to weather even the most forceful arguments for resistance to the authority of a "Supreme Power." ${ }^{20}$ While the details are sketchy at best, he seems to have chosen excellent company.

Saint Socrates, that doctor of ills to the soul as well as to the body politic, stands of course at the head of the line. Furthermore, Reid adds, any "who have power or have any share of the Legislature ought to be very watchfull to discover the diseases of the body politick and to apply timely remedies." The plea for "timely remedies" has to be viewed, however, in the context of the "great mischiefs arising from violent changes of Government," which show "that they ought not to be attempted without urgent Necessity." It requires little imagination to conjure up the sort of picture which the prelector may have tried to paint for his students with that notion of "urgent Necessity." The list of names attached to his treatment of "the Doctrine of Non Resistance" itself suggests a colourful skirmish of ideas within a particular historical moment. Reid's text at this point reads simply: "The Opinion of [Grotius]. 
Filmer \& Leslie and Atterbury. Sidney Locke Milton Hoadly." ${ }^{21}$ In itself seemingly innocent of preference this same list, enlarged within a year to give fuller scope to the issues, will begin to divulge more than just a hint of the prelector's early position.

Once more, Reid's starting-point is the "End of Government, to wit the Good of the Body politick." Measured according to that end, the "Rights and obligations" inherent in and binding upon a sovereign power and its subjects are clearly definable. Hence, it is the right of the sovereign, to which respect and obedience are due, to order all "things that are lawfull and are not contrary to the Public Good or to the Constitution." Conversely, "in things unlawfull" obedience may be withheld; moreover subjects are entitled "to defend their Rights against a general \& violent Oppression."22 Reid's arguments in support of resistance swing still further in the direction and apparent favour of the rights of subjects as he cites, but turns against him, Calvin's own example of Nebuchadnezzar. ${ }^{23}$ A "proud Monarch," he contends, who sets up his own "Gods" or "Golden Image" in opposition to divine authority must be resisted not for political ends, but in the name of "true religion" (in Knox's phrase); for as several earlier challengers to Calvin's authority had maintained, an impious sovereign violates, and thereby puts himself outside, the very covenant by which he was ordained to rule. ${ }^{24}$ Reid's exposition of the intricacies of the resistance debate was by no means restricted, however, to scriptural or theological sources.

In September, 1766, Reid makes note of the fact, as was his practice, that he had read "The Law of Nations; or Principles of the Law of Nature applied to the Conduct and affairs of Nations and Sovereigns by M. de Vattel."2s Although there is a curious discrepancy between the date of his first lecture from these notes (April, 1766) and his reading of de Vattel's work, Reid has clearly been sufficiently impressed by its argument to make it a staple feature of what seems to have become his annual reaffirmation of the principle, that "Active Obedience [is] due onely in things lawfull." 26 Those portions of the "Extracts" designated by a marginal note for citation in class and already mentioned, in substance, on the preceding folio, were presumably intended to give graphic illustration to that vital and singular point on which alone resistance to a sovereign might be countenanced; namely, that the "Supreme power in doing Hurt to the Society Acts without Authority, from God, Reason, or human Laws." ${ }^{27}$ Nevertheless, while there might well be instances of commands deemed unlawful or socially injurious, or possessing moral turpitude, there must surely be other conditions under which resistance of any sort would be unwarranted.

Again, if only briefly, the "Example of Socrates" is resurrected to redress an apparent disproportion in Reid's argument. Even "where Our Rights are violated," obedience is fitting "wherever the publick good requires it." Unfortunately for the doctrine of non-resistance, however, that measure of "the publick good" can be applied both ways. Socrates notwithstanding, therefore, where "Resistance is necessary to save a Nation from tyrrany it is not onely Lawfull but laudable \& glorious." Not even the "Precepts of Scripture" can save the non-resistor here, for they are but "General Precepts 
which therefore admit of Exceptions." Has Calvin then been completely undone?

Apparently not, or at least not fully; for an important "Qualification" one which, it may be recalled, had been employed during Reid's preliminary assessment of the case in 1765, - is now admitted. "The Causes of Resistance ought to be great and Evident . . . All the certain and probable Consequences of it duly weighed." It is the first of several cautionary notes to be sounded in the discussion; admonitions which include an apparently late addendum which reads, "The Evils arising from Resistance greater than those that arise from Suffering"; a conciliatory gesture in the form, "This Doctrine does not encourage Rebelion, nor tend to disturb Government"; and Reid's final words on the subject at this stage: "Changes in a form of Government that hath been established \& acquiesced in ought not to be made without very weighty Reasons[.] Every Good Man respects the Laws and Government."28 But ultimately, it is the moderate and well-tuned voices of Grotius and, to a lesser extent, Pufendorf which triumph in the end. Both, as Reid appears pleased to affirm, "seem to Give with one hand \& [take] with the other." 29

3. The spirit of "give and take" seems likewise to determine Reid's attitude during his closing lectures of the term, on the subject of "Politicks." Throughout the period under review, and certainly prior to 1776 , the issue comes regularly to the fore during Reid's rather lengthy exposition of despotism. Nevertheless, having once planted resistance under that head, Reid quickly withdraws it, preferring instead to place it under "Political Jurisprudence." ${ }_{30}$ This rearrangement of parts was no doubt made necessary by his conviction that the domain of Politicks ought to be distinguished from that of Political Jurisprudence as well as from Morals, on which in fact the latter is founded. (As Reid is quick to explain: "All Questions belonging to Jurisprudence are Questions concerning Right and wrong." ${ }^{31}$ ) The question of the right of resistance to magisterial authority is one which may be regarded, as he himself acknowledges elsewhere, "either in a political or in a Moral Light." In respect of the latter, however, it belongs to that type of query which is concerned, for example, with the rightness or wrongness of the "Tolleration [sic] of those who are not of the established Religion." ${ }^{32}$ What then, within the context of a despotic regime, is Reid's moral verdict of that "Right"?

Although it may be reckoned an extreme case, despotic rule affords Reid the opportunity of illustrating two essential conditions of government failing which resistance becomes, to his mind, justified. In the first place, the governed may be said to resemble a moneylender who, when entrusting money to any "Debitor," insists that the latter provide "a Security" against the "just Restitution" of the loan. There is no question here of the integrity of the debitor, nor will any "Debitor however honest [take] it ill that men who entrust him with their Money should take such a Security." It is characteristic of despotism, however, that "there can be no such security," for the simple reason that there is "no Law according to which [the despot] is obliged to Judge." Secondly, the "Rights of Mankind" (to which, incidentally, Reid later adds the rights of domestic animals) provide that any laws set over an 
individual "be framed and directed with a view to the good \& happiness of the Subject." Any law "not directed to this End" is thereby to be judged "contrary to the rights of Mankind." Of course, legislators may mistake the "publick good even when they intend it"; but due allowance being made for such error, the resulting "grievance" will in time be "remedied." ${ }^{33}$ In the case of the despot, however, no redress to time or "Experience" is possible, for the good of the public was never his intention. ${ }^{34}$ Neither of these conditions being met, therefore, the subject finds himself in a position where, assuming certain other factors, he may have recourse to some form of resistance.

The spelling out of these further impediments to resistance now becomes necessary; for as Reid had observed, in his first account of despotic rule, such "cruel Bashes" of which the "Seraglio" might never hear will, in time, so discourage the one who suffers them that, "banishing all thought of the future and reflexion upon the past [he will sing] in his Chains like a bird confined to a Cage and [make] the best of the present Moment." ${ }^{35}$ To the right of resistance, then, one must add the enlightenment to understand and the power to seize that right. Gathering these factors together, Reid pronounces his verdict:

Every Government . . . which is not directed to promote the good of the Governed is a Usurpation without Right nor can any Length of Time give it a just Title. The people may be subject through fear or through ignorance. But if they are sufficiently enlightened to understand the Rights that belong to them as men, And if at the same time they have it in their power to shake it off and to establish a better and more equitable Government, I have no doubt but they have as good Right to do it as a man has to defend himself against a high way man. ${ }^{36}$

Unlike his classical mentor, Cicero, Reid does not rage against the tyrant. ${ }^{37}$ Nevertheless, the calmness of his reasoning scarce conceals the firmness of his resolution.

The inferring of such a right from a set of conditions under which, alone, he who governs may assume and perpetuate that title is not, of course, exceptional. It had long been argued $^{38}$ that, armed with the right of free disposition and constitutionally stationed supra regem, an entire people or at the very least a representative council or assembly may be entitled to depose a pernicious or worthless ruler. ${ }^{39}$ Reid's "constitutional" references are seemingly of more recent stock, ${ }^{40}$ but serve equally his insistence on the "Importance of Stating truly the Submission due to the Sovereign Power[;] to Princes and to the People, to mankind in General." ${ }_{41}$ The conditions, that is, must be well laid; for should any people be compelled to decide, at a critical juncture in their history, whether to claim or to forfeit the right to resist, such conditions will be their only hope against vacillation and possibly prolonged suffering. ${ }^{42}$

4. What happens during what we might call the "middle period" of Reid's deliberations is in fact only a prelude to the apparent vacillations which attend his response to the events of the French Revolution. Although the evidence for this stage is quite patchy - an unseemly mixture of indirect and 
fragmentary sources, - it rather suggests that when the theoretically impossible does in fact take place, Reid's argument experiences an uneasy shifting of ground, a temporary dislocation of concepts. Since Reid has been accused of "[bowing] to the [later] storm" and so of running straight from principle into safer confines, ${ }^{43}$ it is well to remember that by 1794 he had already weathered one such upheaval, by facing up to the implications of its most unsettling questions.

Rather surprisingly, what emerges from the reconstructed picture gleaned in part from a student's notes, and in part from Reid's expressed position on several subjects, ${ }^{44}$ - is a newly-formed regard for the ultimate right of the state to modify or abrogate the individual's right of private ownership. In view of his generally favourable estimate of Locke's position on this score, as well as his professed admiration for certain provisions made in the Charter of Charles II to William Penn in $1681,{ }^{45}$ Reid might almost be said to court inconsistency here. In earlier pronouncements, he had either reasoned out or at least given tacit assent to two principles: first, that the "Right of Property," while not being "natural" but rather "acquired by [a man's] actions or the Actions of other Men," is inviolable ${ }^{46}$; and second, that any imposition of taxation or customs on a subject's "Lands tenements goods [or] Chattels" wihout the consent of the "Proprietary, or chief Governour, or Assembly, or by Act of Parliament in England" would be tantamount to an attempt to remove or confiscate that property. ${ }^{47}$ That a magistrate is bound to "preserve" and never to "take away and destroy the property of the people" had, of course, been a central tenet of Locke's argument in the Two Treatises and, more specifically, of his definition of tyranny. ${ }^{48}$ Yet if Reid's previous strictures against tyranny had implied acceptance of such a definition, and hence agreement with Locke, on Monday 29th April, 1776, he seems to have made an about-face.

Responding to the contingencies of the historical moment, Reid elects to examine a question "much disputed upon now[,] whether people in a free state should be taxed against their consent." ${ }_{49}$ It is, he admits, "a strange notion" and Locke has unfortunately been used. Nevertheless, as he had maintained only a week before, on 26th April, the right of the state to impose taxes or to expropriate property "for the common advantage" (the right known as dominium eminens) cannot be denied even "by the American Colonies" now, alas, "very hurtfully taken" with this "notion of Mr Locke." s0 What appears to be "hurtful" in Locke's account is his over-emphasis upon the defence of property as the end of government; the absence of "his usual acuteness [in considering] that the Intention of man's entering into society is ... [equally] to defend his Life his honour, \& his esteem . . ." and his failure to recognize that by analogy with the private debtor who refuses to pay, anyone who resists the paying of a tax imposed by the state "may be forced to do it. . . ." Locke's counsel to the Americal colonists, it seems, had been rather careless in the delivery, but even more incautiously received.

If this was indeed Reid's argument during that period - and there is no compelling reason to doubt the reliability of Jack's record of it, - it would seem that Reid was already moving towards an elucidation of that position which, eighteen years later, he would defend even more openly. The voices of 
resistance in the American colonies had apparently met their own in the classroom of the Scottish prelector. Perhaps the latter's reading of de Lolme's Constitution of England in January of that year had helped to stiffen his own resistance; for among the "Advantages of the british [sic] Constitution" which he extracts from the Genevan's work, Reid singles out for particular attention the "placing the Executive power in One \& making it hereditary." This, he seems ready to agree, "renders [that power] sacred \& inexpugnable. [It] Checks the Ambition of such as in Republicks from engrossing power have become tyrants, \& prevents any Citizen from ever rising to a dangerous greatness." ${ }_{11}$ Nevertheless, the challenge of that republicanism was to be sounded once more within Reid's lifetime. Before finally alerting his fellows to the real "Danger of Political Innovation," he would find himself beleaguered, if not actually tempted by the clarion call of French resistance. What, then, was his position at the close?

5. From all accounts, the road to Reid's last stand was a difficult and perhaps even humiliating one. In the first flush of revolutionary enthusiasm, he seems like others to have been raised aloft on the eloquent optimism of Sir James Mackintosh's Vindiciae Gallicae. ${ }^{52}$ Indeed, the very passion of that plea for "a new aera in history," ushered in by "the authors of the greatest attempt that has hitherto been made in the cause of man," 53 might almost have played the cathartic to Reid's misgivings. For Mackintosh railed against what he called this "dread of innovation - this horror at any remedy," and would by "reason" have exorcised such fears of a "bolder navigation." The enemy alike of "dastardly coasting" and of "philosophers in theory, and barbarians in practice," ${ }^{4}$ Mackintosh stoked the fires of a "virtuous enthusiasm of liberty"; had events not proved otherwise, he might even have convinced Reid that, unlike the religious sort, this "fanaticism" was not at all "transitory." But it was just that and Reid is purported to have denied its spirit, even after supporting the National Assembly with funds.

Reid's involvement in the first wave of British response to events in France has been variously portrayed not always, it must be said, to his credit. The sardonic allusion of Beattie's friend, Robert Arbuthnot, to the "venerable" Dr. Reid's weakness in remitting money in support of the revolutionary cause leaves a bitter, but unsatisfied taste. ${ }^{55}$ Perhaps more reliable are the views of the Rev. Archibald Arthur, an early ally and later assistant of Reid, ${ }^{56}$ whose "sentiments ... concerning the British constitution," are said to have "coincided with those of Dr. Reid, who thought it proper soon after the commencement of the French Revolution, and in the situation in which he was placed, to declare, and allow his opinion on this important subject to be published." ${ }^{57}$ Unfortunately, the substance of those "sentiments" appears to have been elicited from both men in declarations dated from as late as 1794 . To be sure, what they convey is compatible with the tone of Reid's discourse before the Literary Society, a tone which, ironically, reflects that very "dread of innovation" of which Mackintosh had warned so eloquently in 1791, and with which even he himself seems later to have been infected. ${ }^{58}$ At the time of the revolution, his biographer claims, Arthur's

sentiment was the same with what reigned in every upright and virtuous 
bosom. He rejoiced in the emancipation of a nation so vast and powerful. But his rejoicing was not of long continuance. So early as the demolition of the Bastile, his penetrating discernment detected the features of rapacious selfishness, beneath the disguise of a liberal indignation. . . . He saw . . . those alarming taints, which afterwards became a noisome pestilence, to infect the atmosphere of other nations. He heard ... the outcry of licentiousness, and the screams of anarchy; to be succeeded . . . by the dead and stupifying calm of a portentous despotism. He strove, therefore, as far as his influence could properly extend, to resist and oppose the progress of those principles that governed France. ${ }^{59}$

This is obviously "resistance" in retrospect, and it does little to clarify, although it might serve somewhat to balance our picture of the situation. At the very least, it acts as a corrective to the image of an aging and abject Reid "bowing" ignominiously "to the storm."

The fact of the matter is that Reid could later point to a note of misgiving sounded as early as his initial, and otherwise unqualified, enthusiasm for the "Liberty" not only of the French but of any nation. Although the evidence remains fragmentary, it is known that Reid acted as one of four "stewards" to a meeting of "the Friends of Liberty in Glasgow," held on 14 July, 1791. An advertisement announcing what he himself subsequently described as "a meeting of Friends to the French Revolution" had appeared in The Glasgow Mercury on 5 July, with Reid's name listed among the stewards at the bottom. ${ }^{60}$ An undated draft of a letter to an unknown party further substantiates and elucidates his involvement in this body. ${ }^{61}$ In the spirit of Archibald Arthur's "sentiments", Reid "Rejoice[s] in that Revolution" and with "those who taste the Sweets of Liberty"; for the freedom of a nation, he holds, must reflect a basic knowledge of the "Rights of Man." He is anxious, however, that those who have recently discovered freedom "may not turn giddy but make a wise and sober Use of it." He is concerned, moreover, that friendship with the Revolution should not be construed as enmity towards "the Constitution of . . . Britain." Indeed, he is emphatic that he had only allowed his "Name to be used" (in the advertisement) "upon the Condition \& promise of my fellow Stewarts that no unfavourable Reflection direct or oblique either on the Constitution or present Administration, of Great Britain was to be heard." Against an "Anomymous letter in a feigned hand," which he has just received, warning both him and his friends ("political Madmen and Black guards") that they will come to "repent the steps [they] have taken," Reid replies (with self-deprecating wit, but no contrition): "Whether do you think it more odd[:] that an old deaf Dolard should be announced as a Stewart of such a Meeting, or that it should give any Man such offence." While Reid might be seen here as smarting a bit under the public's misrepresentation of his good intentions and (more importantly) of his strict conditions of alliance, he holds resolutely to the position that he has neither said nor done anything of which he need repent.

Nevertheless, if Reid did not recant, having nothing worse to take back than his "rejoicing" at an emancipation so short-lived, he did make a rational virtue out of the "dread of innovation." From the outset, in 1794, he makes it 
clear that his discourse does not concern the abstract question, which "form, or order of political society . . . tends most to the improvement and happiness of man?" Rather, it has to do with the "very dangerous" practical question, how a "long established" and actually existing form of government "may be changed, and reduced to a form which we think more eligible?" His answer, moreover, is brutally realistic: such a change can only be accomplished with great difficulty and, in all likelihood, with much loss. Although this estimate regards only "violent and sudden changes," and not those which are "gradual, peacable and legal," Reid's conclusion (as he says "from the whole") is that

such changes are so dangerous in the attempt, so uncertain in the issue, and so dismal and destructive in the means by which they are brought about, that it must be a very bad form of government indeed, with circumstances very favourable to a change concurring, that it will justify a wise and good man in putting a hand to them. ${ }^{62}$

The reasons for this bleak prospect are likewise severely drawn: no change of this order and magnitude (that is, in a "great nation") could be effected "all at once," by an ignorant multitude in company with a self-interested faction of "the knowing," whether by open consultation, by election, or even by a constitutional assembly. Human nature, Reid concedes, will simply not support "such a supposition."

Clearly, the only principle at work here is that of consequences; not whether the laws of an existing form of government should always be obeyed (Socrates' argument in the Crito 50b-5lc), but what would happen if . . . . And while the utter wretchedness of a particularly bad government might be grounds for a "wise and good man" to put his hand to it to raze it, even that malignity must be weighed against the effects of resistance. It would appear, then, that Reid has not after all been swayed from that position enunciated during the first few years of his lectures at Glasgow. "The Evils arising from Resistance," he had cautioned at that time, are "greater than those that arise from Suffering."

6. Was this the reasoning of a Socrates? Was it indeed, like the conduct of that ancient figure, "worthy of [a] Prince of Philosophers"? Reid apparently thought so. Both his final declaration and his early arguments draw to a close on a similar note: a note not only of dutiful, if necessary of passive, obedience, but also of positive goodness.

"Every Good Man," Reid had affirmed, "respects the Laws and Government of his Country." ${ }_{63}$ The implications for the resistance fighter could not be more obvious; nor on this condition could the security of any government be better assured. The obligations, of course, are "reciprocal": "[protection] and the benefit of laws on one hand; respect, submission, and defence in time of danger, on the other." Yet the reciprocity is scarcely one of equals for, as Socrates also had assumed, the protector must play the "father" to the child. Hence, in spite of Reid's late attempt to dress up reform in the guise of "that candour and indulgence with which we perceive the defects of our dearest friends," this is in truth a reformation headed by good men who "lead quiet and peaceable lives in all godliness and honesty'." ${ }^{64}$ Now clearly 
the victor, the Calvinist principle of obedience puts to lasting rest, at least in Reid's mind, the agonizing antinomies of an earlier prelection and upholds, against either theological or more radical dissenters, the duty to nonresistance. ${ }^{65}$ Consequently, if "Sancte Socrates" may be heard once more in the midst of these reflections, it is as a celebration of divine authority as much as of reason.

\author{
J.C. Stewart-Robertson \\ University of New Brunswick
}

\title{
Notes
}

This is a considerably shortened version of a paper originally read for the Canadian Society for Eighteenth-Century Studies in May, 1980.

'Pringle's analysis is recorded in dictates "Collected by JBPS" in 1741 from "Lectures from Cicero by Dr. John Pringle, Professor of Moral Philosophy att Edinr.," Edinburgh University Library, MS. GEN. 74D (ff. 8-45). In large measure a commentary on Cicero's De Officiis, Pringle's lecture material seems here to adopt a more independent line, as he criticizes that ancient writer's defence of "Catos Exit" [sic] on the grounds that the latter's death failed of the highest sanction for suicide; namely, that the act be (morally) "examplary." (Wherever possible in what follows, I have retained the spelling of the original MSS., making exception only for conjectural readings and for the rendering in full of certain conjunctive or pronominal abbreviations.) The particular passage which triggers Pringle's antinomy on selfmurder appears at De Officiis, 112: "suicide may be for one man a duty, for another [under the same circumstances] a crime" (W. Miller, tr., Loeb Classical edition).

${ }^{2}$ Phaedo 61c-62c. Pringle's argument against Socrates is that "according to the Established Maxim that Evry Man who rejects the Means of [providing for] Life is his own murderer in Effect So Socrates," having refused all means of escape, is thereby "guilty" by omission and of his own choice. (The words "providing for" are a conjectural reading of an indistinct text, of which the first three letters only are apparent.)

${ }^{3}$ Significantly, Pringle's complaint against Cicero's reading of the "Exit" of Marcus Cato is at one with that of Desiderius Erasmus who, in "The Godly Feast," demures at Cato's going out as being rather "expressive of ... pride" than of the humility and hope which ought to characterize the suicide. With respect to the last-named qualities, Erasmus is more generous, less grudging, in his honouring of Socrates. (His reference is also rather to Cato's final speech in De Senectute.) See The Colloquies of Erasmus, tr. Craig R. Thompson (Chicago and London: University of Chicago Press, 1965), pp. 66-68.

${ }^{4}$ In Observations upon Liberal Education In all its Branches (London, 1742), Pt. III, ch. 1, 2.

s Reid made frequent use of the analogy in his lectures on the "Culture of the Mind," delivered to his special "12 o'clock" classes at Glasgow College after 1764.

6 "A brief Account of the Nature, Progress and Origin of Philosophy delivered by the late Mr. David Fordyce," and presumably transcribed by "his Scholars, before they begun [sic] their Philosophical course. Anno 1743/44," Aberdeen University Library, MS. 184.

' Gregorie's topic (\#30) reads, "Whether the Socratic method of Instruction or that of Prelection is preferable?" and is dated " $8 \mathrm{Jan}$. 1760." An earlier topic (\#31) on the "ancient Method of Education in Public Seminaries from earliest Infancy," again in relation to "modern practice," had been delivered by Dr. David Skene on 27 November, 1759. The last in this particular group of topics (\#'s 30 to 37), regarding the best means of cultivating the young "for the different businesses of life," was given by Professor Gerard. See the original list of "Questions Proposed in the Philosophical Society in Aberdeen," under the authors' respective hands, in AUL, MS. 539. I have treated of the still wider setting of these queries in "The WellPrincipled Savage, or the Child of the Scottish Enlightenment," Journal of the History of Ideas, 42, 3 (July-Sept. 1981), 503-25.

${ }^{8}$ See Gerard's Plan of Education in the Marischal College and University of Aberdeen, with the Reasons of it (Aberdeen, 1755), p. 22. 
${ }^{9}$ Dialogues concerning Education (London, 1745-48). Reid twice pays tribute to Fordyce's stature as a philosopher of education, in MSS. $2131 / 4 / \mathrm{I} / 18$ and $4 / \mathrm{I} / 31$.

10 Dialogues, VIII, 197. The Socratic method is perhaps nowhere better depicted.

1 For this distinction, see Cicero, De Officiis, 107.

12 MS. 2131/8/IV/10 (f. 4); "their" is somewhat indistinct, but highly probable; the phrase "respect and" which follows has been lined out. The numbering scheme for the Reid MSS. is that agreed to by the editor of the Birkwood Collection in co-operation with Mr. Colin A. McLaren, the Archivist and Keeper of Manuscripts, Aberdeen University Library, for the forthcoming serial publication of Reid's papers. The folio numbers are based on my editing to date, and may therefore be subject in some instances to a final revision.

${ }^{13}$ In "The Godly Feast," the dying words of Peter, Cato, Paul, and Socrates tend to blend into a paean of hope in death. In that mood, moreover, the sanctification of Socrates seems virtually inevitable: "I can hardly help exclaiming," says the character Nephalius, "Saint Socrates pray for us!"

14 In Reid's very first sketches for a "division of Pneumatology" - undated, but because of their form, script, and resemblance to the lecture notes of his first year, presumed to derive from the period 1764-65, - "Jurisprudence" is not specifically mentioned, although "Ethicks" and "Politicks" are slated to occupy those final segments of the course: vide MS. 2131/4/II/11. We do know, however, from lecture notes for the spring sessions of 1765 and 1766 , that Jurisprudence took up a position immediately following Reid's treatment of "Justice" - which he had designated, contra Cicero, to be the last of the Cardinal Virtues, - this analysis itself falling under the general heading of "Practical Ethicks" (MS. 2131/8/IV/2 and 1, in that order). In observing this order, Reid does not so much depart from what I call the "Pneumatological Tradition" as, in this instance, simply refine it.

15 MS. 2131/8/IV/9. Although the arrangement of his notes under this head is less than clear, one can, by careful editing and with the occasional help of an external set of notes from one of his students, piece together what appears to have been a fairly standard three-part study. Reid begins with a general appraisal of the "Rights and obligations of men grounded upon the laws of Nature," and proceeds to the "more difficult" cases arising, for example, out of a "great inequality of the Persons" or involving "Primitive Christians under persecution" (MS. 2131/8/IV/4). Following a brief note on the "Adventitious Rights of Mankind," such as "Property" (MS. 2131/8/IV/6). He spends several weeks analyzing the rights of "Succession" and of "Contracts and Covenants," before bringing the first Part of Jurisprudence to a close (MS. 2131/8/IV/7). In that first spring of 1765 "Book 2," which concerns "the Rights \& Duties arising from the Domestick Relat[ions]" (a frayed edge has rendered the final letters indistinct), occupied the period from 2 to 9 April; at which time Reid turned his attention to the "Rights and duties that arise from the political State or that of Civil Goverment" (MS. $2131 / 8 /$ IV $/ 7$ and 10). In the following spring Reid appears to have reworked, in greater detail, his notes for what is now distinctly labeled "Part 3." A short time later, he has added a discussion of the "Rights of States," of the causes of "injustice" between them, and the "Laws of War"; he quotes extensively on these issues from M. de Vattel's The Law of Nations; or Principles of the Law of Nature applied to the Conduct and affairs of Nations and Sovereigns, tr. Newbery (London, 1760), which he had read in "Septr 1766"; cf. MSS. 2131/3/II/5, $8 / \mathrm{IV} / 8$, and $8 / \mathrm{IV} / 9$. With only minor changes or elaborations (for example, MS. $2131 / 3 / \mathrm{II} / 5$, of the "Just Causes of War" $\mathrm{d}$. 1770), the set of lectures is thereby complete. J. Rennie's notes of Beattie's lectures at Marischal College, at about the same time (1767), reveal a similar progression, but move directly under "Politics" after the investigation of "Oeconomics." See Glasgow University Library, MS. Hamilton 55. Beattie's own record of the lectures, in his Elements of Moral Science (Edinburgh, 1790-93), is different again, the analysis of property and contracts having been deleted. We shall see that Reid too effected adjustments, in part to meet the changing times, in part as a reflection of his widening interests and readings.

16 MS. 2131/8/IV/10.

17 In the absence of any direct supporting evidence from Reid's own papers, we are here dependent upon the indirect transcription of one of Reid's more reliable student-auditors, Robert Jack, who, by a piece of good fortune, was in attendance at Reid's lectures during the months of April and May, 1776. His notes of Reid's discussions of Jurisprudence and Politics are virtually complete, the only exception being Reid's introductory session under the former head. See GUL, MS. Gen. 116-8. 
${ }_{18}$ Memorials of his Time (Edinburgh and London, 1910), p. 42. In words that are themselves a memorial, Cockburn remarks further: "Everything rung . . . with the Revolution in France . . . . Everything was soaked in this one event" (73).

19 Jack's Notes, MS. Gen. 118; and "On the Danger of Political Innovation."

${ }^{20}$ MS. 2131/8/IV/10 (ff. 1, 4, 5); dated "Apr 9 1765."

${ }^{21}$ The date is now "Apr 12." The name of Grotius has been lined out here although it reappears, with that of Pufendorf and with a brief exposition of principles, in the text for the following year. Cf. MS. 2131/8/IV/9. The battle lines are also more sharply defined in that subsequent set of notes, and a few names added. Richard Hooker, Algernon Sidney, Locke, and Benjamin Hoadly (Bishop of Bangor, \& c.) are there set "Contra" Hobbes, Sir Robert Filmer, Sir William Barclay (the royalist Governor of Virginia), Alexander Leslie (Earl of Leven), and Francis Atterbury (Bishop of Rochester); in short, against those who had given support, in some manner, to the idea of absolute sovereignty or of the divine origin and right of kingship. See Peter Laslett's very thorough analysis of this clash of ideas in the introduction to his edition of Sir Robert Filmer's Patriarchia and Other Political Works (Oxford: Basil Blackwell, 1949).

${ }_{22}$ MS. 2131/8/IV/9 (ff. 4-5); dated 24 April, 1766.

${ }^{23}$ See John Calvin, Institutes of the Christian Religion, ed. John T. McNeill, tr. F.L. Battles (Philadelphia: The Westminster Press, 1960), II; Bk. IV, ch. xx, pp. 26-27. Reid would seem here to join forces with George Buchanan and John Knox in opposing Calvin's intransigency and in advocating resistance to any ruler violating or defaulting on divine edict. A slight script change, incidentally, at the point of the example (f.5, bottom) may be indicative of a later insertion (a technique not at all uncommon in Reid's notes).

${ }^{24}$ See, for example, Theodore Beza, Vindiciae contra tyrannos (1579) and George Buchanan's De jure regni apud Scotos, of the same year. Quentin Skinner has recently added his voice to the contention that Knox's Appellation from the Sentence Pronounced by the Bishops and Clergy, of 1558 , is "not strictly speaking a political theory at all, since his appeal to the nobility ["to take vengeance upon evil doers (and) to maintain the well doers"] is couched entirely in terms of their alleged religious obligations." The Foundations of Modern Political Thought (Cambridge: Cambridge Univ. Press, 1978), vol. II. p. 211. It was certainly on religious grounds that Calvin gave apparent sanction to resistance through the populares magistratus in his Institutes (IV, xx. p. 31).

${ }^{25}$ Reid's reference continues: "Translated from the French Lond 1760 Newbery \& c. 2 Vol $4^{\circ} 1$ Vol 254 pages 2 d 170"; MS. 2131/3/II/5. This MS. has erroneously been grouped with two miscellaneous folios (one an abstract of "Lord Herberts Book de Veritate," the other a page from his Jurisprudence notes on the "Just Causes of War"), and unfortunately separated from the remainder of Reid's extracts from the de Vattel work. These have been traced by means of the page numbers and the alphabetical letters according to which Reid identified certain extracts for inclusion in his lecture materials, to MS. 2131/4/III/23c.

${ }^{26}$ MS. 2131/8/IV/9 (f. 6).

${ }^{27}$ Ibid.; (italics mine). The marginal note reads: "See Extracts from Vattel p. 25 \&c."

${ }^{28}$ MS. 2131/8/IV/9 (f. 6).

29 "Grotius acknowledges that there are cases of extreme Necessity wherein it may be lawfull to resist the supreme Power" [cf. De Jure Belli ac Pacis (1625), tr. W.S.M. Knight (1922); Bk. II, ch. $x x v$, p. 8].

${ }^{30}$ His instruction, apparently a subsequent insertion into the text, reads: "All that is marked in the Margin in the two preceeding pages [ff. 1-2] by a line drawn from top to bottom belongs to Political Jurisprudence." MS. 2131/4/III/9 (f.3).

${ }^{31}$ MS. 2131/8/IV/9 (f.1).

${ }^{32}$ MS. $2131 / 4 / \mathrm{III} / \dot{3}$.

${ }^{33}$ Due allowance for error on both sides is also readily granted, and indeed stressed, by Hutcheson whose argument, in this respect at least, Reid might be seen to follow. Cf. A Short Introduction to Moral Philosophy, in Three Books; Containing the Elements of Ethicks and the Law of Nature, tr. from the Latin (Glasgow, 1747), III, vii, p. 2; see also III, viii, p. 12.

${ }^{34}$ MS. 2131/4/III/9 (f.2); dated 6 May, 1765: "where the publick good is not intended there is no remedy to be expected."

${ }^{35}$ MS. 2131/4/III/5 (ff. 1-2).

${ }^{36}$ MS. 2131/4/III/9 (f.2).

${ }^{37}$ Cf. De Officiis, III, 32. 
${ }^{38}$ By Jean Gerson and John Mair, for example, or later by Lutheran and Calvinist reformers; see Quentin Skinner, pp. 116-23, 206-13.

${ }^{39}$ Cf. MS. 2131/8/IV/9 (f.5).

${ }^{40}$ De Vattel appears again to have been his immediate source, but the arguments of Milton, Sidney, and Locke would almost certainly have been well aired during his expositon of "the Controversy ... raised and carried on in England" a century earlier. It is unfortunately impossible to infer from the documentary evidence of this first period, for example, just how Reid might have treated Milton's Defensio pro populo Anglicano (published in 1651). In the light of his final thoughts on the subject, however, one might hazard the conjecture that Reid may have found himself more than a little sympathetic with the cautious views of Milton's opponent, the French "grammarian" Salmasius.

${ }^{41}$ MS. 2131/8/IV/9 (f.6).

${ }^{42}$ Not the least of Reid's sources at this time was Harrington's Oceana. "The Author was a Man of great Genius . . .," extolled Reid (MS. 2131/4/III/6), who was nevertheless severely critical of this writer on a number of counts. Although I was able to treat at length of Reid's attack on the Harringtonian "Model" in the original paper, the limitations of space do not permit its inclusion here.

${ }^{43}$ Henry W. Meikle, Scotland and the French Revolution (1912; rpt. New York: Augustus M. Kelley, 1969), pp. 155-56.

${ }^{44}$ The notes are those of "Robert Jack" and, by a quite fortunate concidence, were transcribed during the critical winter and spring of 1775-76. Their value for our purposes lies in the fact, not only that they reveal an unusually careful literary hand, but also that they have been meticulously arranged and chronicled. See GUL, Gen 116-18. Among Reid's own papers, those touching on commerce with the colonies; on Charles the Second's Charter to William Penn; on the Right of Property; and on taxation, have been most useful. See MSS. $2131 / 4 / \mathrm{III} / 15,4 / \mathrm{III} / 19,4 / \mathrm{III} / 18$, and $4 / \mathrm{III} / 10$. For the most part, these originate in an earlier climate of lecturing needs, and thus comprise the structural components on which Reid is known to have based his subsequent presentations, with only minor additions and modifications. That at least seems to be the inference to be drawn from the extant lecturenotes themselves. The fact that Jack's transcription can only be matched in part against even the most fragmentary of the original notes would seem to point, therefore, towards a topical, possibly extemporaneous, and ad hoc delivery, apparently dictated by a genuine concern for the sudden and dramatic reversals in colonial administration during the years 1775 and 1776 .

${ }_{45}$ MS. 2131/4/III/19. Reid logs his reading of the Charter as having taken place on "Aug 27 1768."

${ }^{46}$ MS. 2131/4/III/18. The balance struck by Reid between "common" and "private" holdings or ownership owes much, probably directly, to Grotius but ultimately, as Reid himself owns, to the "ancient Moralists"; Cicero, for example, in De Officiis, I, 21-22; or Aristotle in his Politics, II, 5.

${ }^{47}$ The phrases cited are derived from Reid's transcription of "The Charter of Cha $2^{\mathrm{d}}$ to William Penn Proprietary \& Governour of Pensilvania 4th March 168l"; MS. 2131/4/III/19. See further Quentin Skinner's interpretation of the seeming contradiction in Bodin's defence both of private property and of absolute sovereignty; Skinner, II, 296-97.

${ }^{48}$ Cf. An Essay. . . of Civil Government, XVIII, 199, XIX, 22, 226, 228, 229.

${ }^{49}$ From the notes of Robert Jack, MS. Gen. 116-18; Lecture CXXI, (f. 673).

${ }^{\text {so }} \mathrm{L}$. CXX, pp. 665,667 . Reid rightly stresses the essential compatibility of the state's dominium universale - as Gierke calls it, "a sort of over-ownership," - with the ownership of the res privatorum, or the dominium appropriatus et specialius of individuals. Only in times of crisis (de necessitate), when the state is unable to defend the public advantage (and thereby the private property of each individual) except by taking steps to use or otherwise expropriate portions of that same property, does the dominium eminens overrule its "special" counterpart. Even then, as Reid is quick to add, the owner of private property must receive proper indemnification for his loss. The imposing of taxes Reid simply believes to be "another exercise of this dominium eminens." MS. Gen. 116-18; L. CXX, 666. For a detailed examination of the concept's history, see Otto von Gierke, Political Theories of the Middle Age, tr. F.W. Maitland (Boston: Beacon Press, 1958), pp. 79-80, 178-79n.. To someone like Thomas Paine, of course, there was no 'common sense' whatever in such an argument. See his address to the "Inhabitants of America" published under that title (Common Sense) on 10 
January, 1776; particularly the section headed, "Thoughts on the Present State of American Affairs."

${ }^{51}$ MSS. 2131/4/III/23a, 4/III/12, 4/III/13. Reid enters his reading for "10 Jan 1776 " under the caption, "Read The Constitution of England or an Account of the English Government by J L

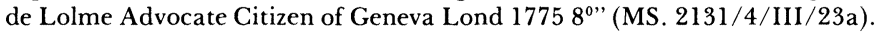

${ }_{52}$ Vindiciae Gallicae. A Defence of the French Revolution and its English Admirers (1791).

${ }^{3}$ See Vindiciae Gallicae, in The Miscellaneous Works of the Right Honourable Sir James Mackintosh (Philadelphia, 1848), pp. 423, 424.

${ }_{54}$ "It is absurd," he writes, "to expect, but it is not absurd to pursue perfection. It is absurd to acquiesce in evils, of which the remedy is obvious, because they are less grievous than those which are endured by others." Vindiciae Gallicae, pp. 422-23.

${ }_{55}$ The reference to Reid's folly appears in a letter from Arbuthnot to Beattie in August, 1792, and is quoted by Margaret Forbes in Beattie and his Friends (Westminister, 1904) p. 272.

${ }^{56}$ He was an "Ally" in the internal struggles which seem to have rocked the Literary Society of Glasgow, during the winter of 1778.79 and on the side of a stricter adherence to the Society's regulations. See Davis D. McElroy's "circumstantial" account of these struggles in his Scotland's Age of Improvement: A Survey of Eighteenth-Century Literary Clubs and Societies (Seattle: Washington State Univ. Press, 1969), Introduction and pp. 41-43.

${ }^{57}$ See "An Account of some Particulars in the Life and Character of the Rev. Mr. Archibald Arthur, late Professor of Moral Philosophy in the University of Glasgow," by William Richardson; in Archibald Arthur, Discourses on Theological \& Literary Subjects (Glasgow, 1803), Appendix I, p. 514n..

58 "In the course of the years 1791-92," explains William Ferguson, "the bulk of the upper classes sought refuge in Burke's passionate rhetoric, while the diminishing ranks of upper-class and middle-class reformers availed themselves of James Mackintosh's reply to Burke, Vindiciae Gallicae . . . Mackintosh was a young Scot who had tried both medicine and law none too successfully and who was launched on a moderately successful political career by this controversy. He later repented of his early democratic sympathies (as so many in his situation did) and became a fulsome adulator of Burke." Scotland: 1689 to the Present (Edinburgh: Oliver and Boyd, 1968), pp. 249-50 (italics mine). There is no evidence that Reid "repented" in quite that sense; nor does his pronouncement "On the Danger of Political Innovation" in any way suggest a contrite spirit.

${ }^{59}$ Richardson, p. 512.

${ }^{60}$ The advertisement, headed "ANNIVERSARY of the REVOLUTION in FRANCE" (it being in fact the "SECOND"), makes it explicit that its "sole object" is "to celebrate, as a subject of exultation, the overthrow of despotism, and the establishment of civil and religious liberty in France" and thereby, through this testimonial, "to promote the general liberty and happiness of the world."

${ }^{61}$ The draft letter appears on a single sheet of folio (recto), opposite a geometrical figure: MS. $2131 / 3 /$ III $/ 8$.

62 "On the Danger . . ." (italics mine); in the original - lately recovered, - MS. 3061/6 (f. 4).

${ }^{63}$ MS. 2131/8/IV $/ 9$.

${ }^{64}$ MS. 3061/6 (f. 27); the quotation is from 1 Timothy 2: 1-2.

${ }^{65}$ Significantly, Reid ends his discourse with that same scriptural passage on which Calvin had rested so much of his case for "obedience"; see the Institutes, IV, xx. p. 23. 